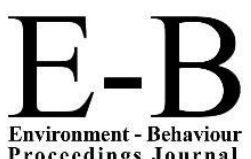

Proceedings Journal
GTSD 2018

https://gtsd.uitm.edu.my/index.php/2014-09-11-18-03-24/2017

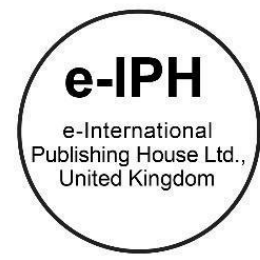

\title{
Awareness and Acceptance in Using Smart Meter by Energy Customers in Malaysia
}

\author{
Siti Rashidah Mohd Nasir ${ }^{1}$, Azmi Ibrahim1, Rohana Hassan ${ }^{1}$, Halilah Haron ${ }^{1}$, \\ Siti Hafizan Hassan1, Siti Laila S. Garieb², Asnawi Busrah ${ }^{3}$
}

${ }^{1}$ Faculty of Civil Engineering, Universiti Teknologi MARA (UiTM), 40450 Shah Alam, Selangor, Malaysia

2 TNB Research SDN. Bhd. (TNBR), Lorong Ayer Hitam, Kawasan Institusi Penyelidikan, Kajang, 43000, Selangor, Malaysia

${ }^{3}$ Construction Project Management Research Group, Universiti Teknologi MARA(UiTM), 40450 Shah Alam, Selangor, Malaysia

sitir015@uitm.edu.my; azmii716@uitm.edu.my; srilaila@tnb.com.my; asnawi.busrah@tnb.com.my 0193571857

\begin{abstract}
The common issues of energy services related to customers' complaints are delays in billing, inaccurate consumption measurement, lack of breakdown information, lack of real-time billing, and energy consumption. A questionnaire survey was conducted using face-to-face methods during the preinstallation phase to determine the customers' awareness, acceptance, knowledge, and benefits in using smart meters. The findings show that $69.6 \%$ of the customers are aware that the use of energy-efficient appliances can save electricity. This study shows that the customers, regardless of demographic profiles and background, portrayed overall good awareness of the smart metering and smart living concept.
\end{abstract}

Keywords: Awareness, Acceptance, Benefit, Smart Meter

eISSN: 2398-4287 @ 2020. The Authors. Published for AMER ABRA cE-Bs by e-International Publishing House, Ltd., UK. This is an open access article under the CC BYNC-ND license (http://creativecommons.org/licenses/by-nc-nd/4.0/). Peer-review under responsibility of AMER (Association of Malaysian Environment-Behaviour Researchers), ABRA (Association of Behavioural Researchers on Asians) and cE-Bs (Centre for Environment-Behaviour Studies), Faculty of Architecture, Planning \& Surveying, Universiti Teknologi MARA, Malaysia. DOI: https://doi.org/10.21834/ebpj.v5iSI2.2519.

\subsection{Introduction}

In the past decade, as electricity consumption has grown at a remarkable rate, so does the development of technology in electricity monitoring and billing. Many countries have already started the smart meter implementation, for example France, Germany, Netherlands, Norway, the United Kingdom, and the United States of America (Zheng et al., 2013). It is estimated that more than 100 million end users are benefiting from smart meter technologies worldwide (US Energy Information Administration, 2014). China has also projected its capital to Beijing to have $100 \%$ smart meter coverage for residential users by the end of 2015 (Anon, 2015). Following the many studies conducted on the development process of the smart meter, there are numerous works of literature which provide an in-depth study on the use of smart meter (Zheng et al., 2013), the related challenges and issues (Depuru et al., 2011), and methods of efficient monitoring (Hao et al., 2012). A recent advance in smart meter networking has enabled fine-grained appliance state monitoring. Hao and Wang (2012) pointed out that to achieve efficient energy control, one important strategy is to monitor the real-time on/off states of electrical appliances using the smart devices which collect these. Efficient energy control will lead to low cost, accurate and scalable energy auditing systems.

eISSN: 2398-4287 ( 2020. The Authors. Published for AMER ABRA cE-Bs by e-International Publishing House, Ltd., UK. This is an open access article under the CC BYNC-ND license (http://creativecommons.org/licenses/by-nc-nd/4.0/). Peer-review under responsibility of AMER (Association of Malaysian Environment-Behaviour Researchers), ABRA (Association of Behavioural Researchers on Asians) and cE-Bs (Centre for Environment-Behaviour Studies), Faculty of Architecture, Planning \& Surveying, Universiti Teknologi MARA, Malaysia.

DOI: https://doi.org/10.21834/ebpj.v5iSI2.2519. 
Compared to a conventional energy meter, the smart meter system is an enhanced energy meter that comprises smart meters, communication infrastructure, and control devices. The control device comprises several sensors that identify key parameters, transfer and process data, and execute command signals. A smart meter can process a combination of parameters such as a unique meter identifier and timestamp of data. It reads real-time data such as the values of voltage, phase angle, frequency, and compute the energy consumption. This vital diagnostic information is then sent to the utility company at prescribed intervals (Depuru et al., 2011). The communication channel is secured and is bi-directional, i.e. in addition to sending data to the utility company, the smart meter system can also receive remote instructions and execute the commands accordingly. For example, the device owner can use a smart meter to monitor and control all home appliances in their premise. The smart meter can also be programmed to bill the users only on the power drawn from the utility grid, i.e. the power drawn from sources owned by the users will not be billed. Smart meters can limit the maximum electricity consumption and can terminate or reconnect the electricity supply remotely (Vojdani, 2008). Smart meters can be foreseen to play an important role in future electricity distribution, as well as usage, performance, and grid load monitoring. Regular data input from the customers will allow the utility companies to manage electricity demand more efficiently and also to advise the customers about the most cost-efficient way to use their appliances.

\subsection{Method}

A quantitative approach using a questionnaire survey was adopted in this study and was conducted during the pre-installation phase. The survey was conducted using mixed survey methods which include a self-administered and face-to-face (door-to-door) survey. The target respondents in this study were the customers of TNB. The study area involves few districts in Melaka which were chosen due to its receptiveness of the Melaka state government to technological changes especially on the smart living initiative. Melaka Tengah and Alor Gajah area were selected by TNB to be involved in the Smart Meter pilot project with the total population of 1500 TNB customers. The questionnaire for customer profiling and survey was designed through extensive literature and also 'syndication and focus group' sessions with the subject matter experts from various departments in TNB which includes TNB Research Sdn. Bhd.; TNB Customer Services Department; TNB Transformation Department; Corporate Planning and Sustainability Department (Regulatory Economics and Planning Division); TNB ICT Division; and TNB smart meter demonstration project team. The questionnaire was designed consisting of four (4) sections, Section A: customer profile; Section B: customers' awareness and knowledge on smart living; Section C: customers' perception, expectation and interest on the smart meter; and Section D: customers' preferences on smart meter features. However, this paper focuses on results and findings based on Section A on the customer profile and Section C on customers' perception, expectation, and interest on the smart meter.

Data was successfully collected from a total of 440 TNB customers within the Melaka area using two questionnaire distribution methods: self-administered (conducted at Melaka International Trade Centre (MITC) during the launching of smart meter event and face-toface/door-to-door around Melaka Tengah and Alor Gajah area. Two (2) types of analyses were used to analyze the data from the questionnaire survey as described in the following sub-sections.

\subsection{Results and Discussion}

A detailed description of the customer profiles is summarized in Table 1. It is observed that the majority (62.4\%) of TNB customers surveyed were males. Almost half (49.7\%) aged between 25 to 44 years with a mere (3.1\%) who were beyond 64 years of age. Close to three quarters $(74.3 \%)$ of the customers surveyed were Malays. Just under one-third $(28.7 \%)$ of the customers came from households with a monthly income of more than RM6000, and approximately two-thirds (64.8\%) of the customers have tertiary education. On average, every household has 4.67 members with a standard deviation of 1.95 members. The total number of members in a household ranged from 1 to 15 . Also, almost all (99\%) customers came from the Melaka Tengah area.

Figure 1 shows the percentage of distribution based on types of customers. Eighty-two percent (82\%) of the premises interviewed are households from residential areas. The rest are from commercial premises while Figure 2 depicts the percentage distribution of customers based on types of residence. Most of those who were from the residential area live in terrace houses (59\%) or semi-detached houses $(33 \%)$.

\subsection{Awareness on Smart Living Program}

The respondents knew about the Smart Living program through sources related to TNB such as door-to-door invitation, brochure, phone invitation, and TNB staff. Information on the program was also obtained from other avenues such as email and workplace. Detailed breakdowns are as shown in Table 2.

The percentages on knowledge and awareness of smart living shown in Table 3 revealed that over two-thirds (69.6\%) of the customers are aware that the use of energy-efficient appliances can save electricity. Meanwhile, knowledge and awareness of the Smart Living concept, the knowledge that energy savings can be achieved through Smart Living practices, and awareness of smart meter have a very similar response within the range of $44.6 \%$ to $47.2 \%$. 
Mohd Nasir, S.R., et.al., GTSD2018ShahAlam, Best Western Hotel i City Shah Alam, Malaysia, 24 Oct 2018, E-BPJ 5(SI2), Dec 2020 (pp.35-41)

Table 1: Percentage distribution of the customers' characteristics

\begin{tabular}{|c|c|c|c|}
\hline \multicolumn{2}{|c|}{ Characteristics } & Number of Customers & $\%$ \\
\hline \multirow{2}{*}{ Gender } & Male & 260 & 62.4 \\
\hline & Female & 157 & 37.6 \\
\hline \multirow{4}{*}{ Age } & Less than 25 years & 8 & 2.1 \\
\hline & $25-44$ & 190 & 49.7 \\
\hline & $45-64$ & 172 & 45.0 \\
\hline & More than 64 years & 12 & 3.1 \\
\hline \multirow{4}{*}{ Race } & Malay & 324 & 74.3 \\
\hline & Chinese & 86 & 19.7 \\
\hline & Indian & 23 & 5.3 \\
\hline & Others (Bangladesh, Nepal \& Eurasian) & 3 & 0.7 \\
\hline \multirow{5}{*}{$\begin{array}{l}\text { Highest educational } \\
\text { qualification }\end{array}$} & Primary school & 4 & 1.0 \\
\hline & Secondary school & 105 & 27.6 \\
\hline & Vocational/Technical & 21 & 5.5 \\
\hline & Tertiary & 247 & 64.8 \\
\hline & Others (Not specified) & 4 & 1.0 \\
\hline \multirow{7}{*}{ Monthly household income } & Less than RM901 & 13 & 3.7 \\
\hline & RM901 - RM2000 & 27 & 7.6 \\
\hline & RM2001 - RM3000 & 45 & 12.7 \\
\hline & RM3001 - RM4000 & 62 & 17.5 \\
\hline & RM4001 - RM5000 & 65 & 18.3 \\
\hline & RM5001 - RM6000 & 41 & 11.5 \\
\hline & More than RM6000 & 102 & 28.7 \\
\hline
\end{tabular}

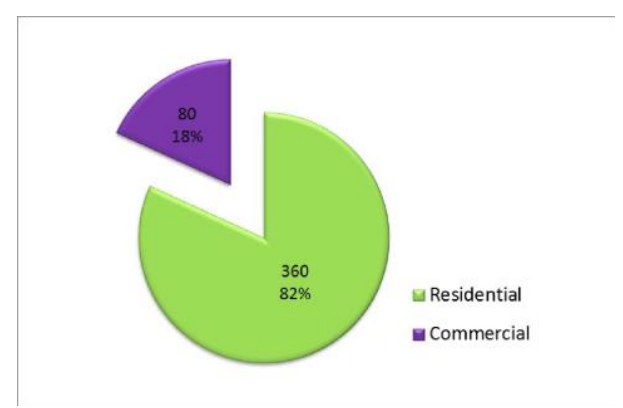

Fig 1: Percentage distribution of type of customer

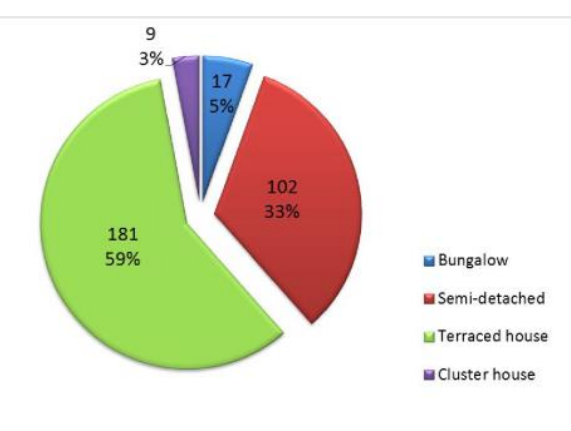

Fig 2: Percentage distribution of type of residence

Table 2: Sources of information on Smart Living program

\begin{tabular}{|l|l|}
\hline Sources & Percentage (\%) \\
\hline Phone invitation by TNB & 7.4 \\
\hline Brochure & 7.9 \\
\hline Other means (email, workplace, and TNB staff) & 12.9 \\
\hline Door-to-door invitation by TNB & 77.8 \\
\hline
\end{tabular}

${ }^{*}$ Customers are allowed for multiple choices

Table 3: Knowledge and awareness of smart living

\begin{tabular}{|c|c|c|c|}
\hline Issue & \multicolumn{3}{|c|}{ Percentage (\%) } \\
\hline & Yes & No & Not sure \\
\hline Do you know and aware of the Smart Living concept? & 44.6 & 35.4 & 20.0 \\
\hline Do you know that energy savings can be achieved through Smart Living practices? & 47.2 & 30.6 & 22.2 \\
\hline Do you know that the use of energy-efficient appliances can save your electricity? & 69.6 & 15.0 & 15.4 \\
\hline Are you aware of Smart meter? & 46.4 & 36.9 & 16.7 \\
\hline
\end{tabular}

Table 4 shows how the respondents are informed about the smart meter. Nearly half of them (45.3\%) heard about a smart meter from the Smart Living Program which was held at MITC, Melaka. Other sources include internet/website $(26.3 \%)$ and word of mouth from family and friends (26.1\%). Meanwhile, $21.5 \%$ of the respondents obtained information from other sources that are not identified. 
Table 4: Sources of information on smart meter

\begin{tabular}{|l|l|}
\hline Sources & Percentage $(\%)$ \\
\hline Smart Living Program with community & 45.3 \\
\hline Internet/website & 26.3 \\
\hline Friends/Family & 26.1 \\
\hline Others & 21.5 \\
\hline Media & 14.4 \\
\hline
\end{tabular}

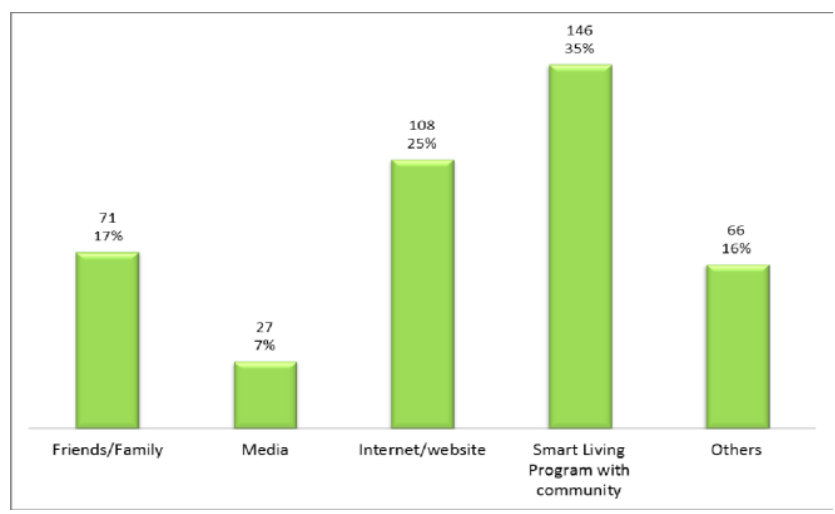

Figure 3: Reliable sources of information on smart meter

Figure 3 shows the different sources of information on a smart meter, the four most reliable sources are the Community Program $(35 \%)$, internet/website $(25 \%)$, other sources (16\%), and family/friends (17\%).

Smart living focuses on developing more sustainable ways of life to achieve energy efficiency. In this study, we observed that customers associate the use of energy-efficient appliances is in line with smart living principles. TNB has invited its customers to the Smart Living Program in Melaka, intending to disseminate information on the smart living concept. This was done through phone invitation, brochures, and email, as well as a door-to-door invitation. The success of the event suggests that the customers trust the information distributed by TNB.

\subsection{Awareness on Smart Meter Benefits}

Reliability analysis carried out on the data collected produces the following results as shown in Table 5.

Table 5: Results of reliability analysis for a full-scale study

\begin{tabular}{|l|l|l|}
\hline Factor & No. of Items & Cronbach's alpha coefficient \\
\hline Usage and technology & 6 & 0.927 \\
\hline Interest on Smart meter features & 7 & 0.900 \\
\hline
\end{tabular}

Cronbach's alpha coefficient values are above 0.70 , which shows that all items asked can measure the factors. Results on the level of awareness on the smart meter benefits are as shown in Table 6 . The percentages reported representing positive responses towards the statement on smart meter benefits. Overall, there is a high positive perception and inclusive of expectation (ranging between $75.6 \%$ to $79.1 \%$ ) on the benefits of smart meter.

Table 6: Awareness of the benefits of smart meter

\begin{tabular}{|l|l|}
\hline Benefits & Percentage (\%) \\
\hline Smart meter technology can assist me to save my electricity usage and cost. & 79.1 \\
\hline The smart meter can realize my dream of owning a Smart Home. & 78.4 \\
\hline The smart meter applications offered to me is user friendly. & 76.9 \\
\hline $\begin{array}{l}\text { An affordable charge with the smart meters' useful features such as real-time monitoring of energy consumption, energy } \\
\text { management/budgeting, smart home applications, etc. }\end{array}$ & 76.4 \\
\hline I know the exact amount of electricity usage based on each appliance used. & 75.7 \\
\hline The Smart meter is easy to install. & 75.6 \\
\hline
\end{tabular}

The majority of the respondents expect savings between $20 \%$ to $60 \%$. In order to achieve this expectation, it is the responsibility of the TNB customers' to embrace the right attitude toward energy savings through the use of efficient appliances and adapting to smart living practices. 


\subsection{Overall Acceptance of Smart Meter}

Up to $86 \%$ of respondents are very interested or interested to own a smart meter as shown in Figure 4 . The expressed interest amongst the respondents is cross-examined with the customer profiles, such as gender, age group, ethnicity, highest educational level, monthly household income, and type of customer, as shown in Figures 5 to 9 . From these figures, it can be observed that those groups who are interested/very interested in owning smart meter are mainly males (55.21\%), aged between 24 to 64 years $(83.1 \%)$, Malays $(65.7 \%)$, have tertiary education (56.8\%), earning more than RM4000 a month (53.0\%) and are residential customers $(71.3 \%)$.

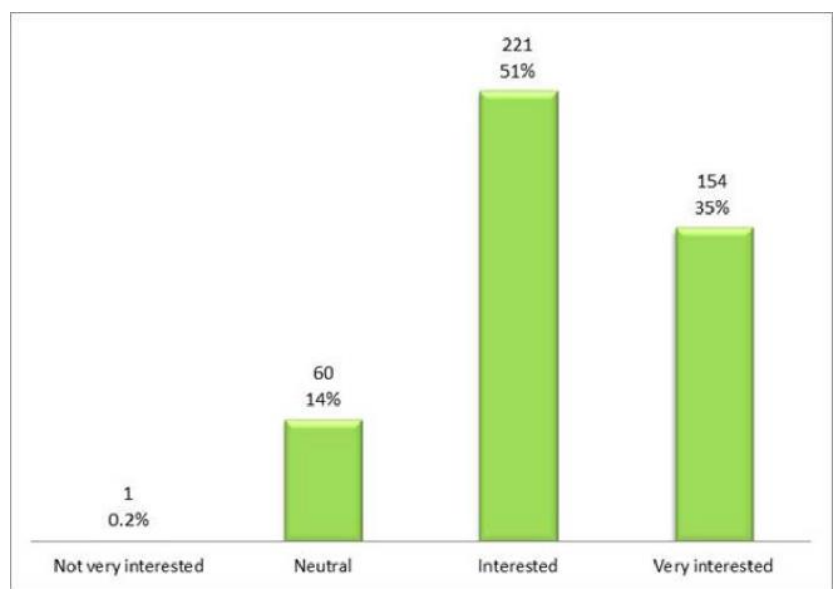

Figure 4: Interest to own a smart meter

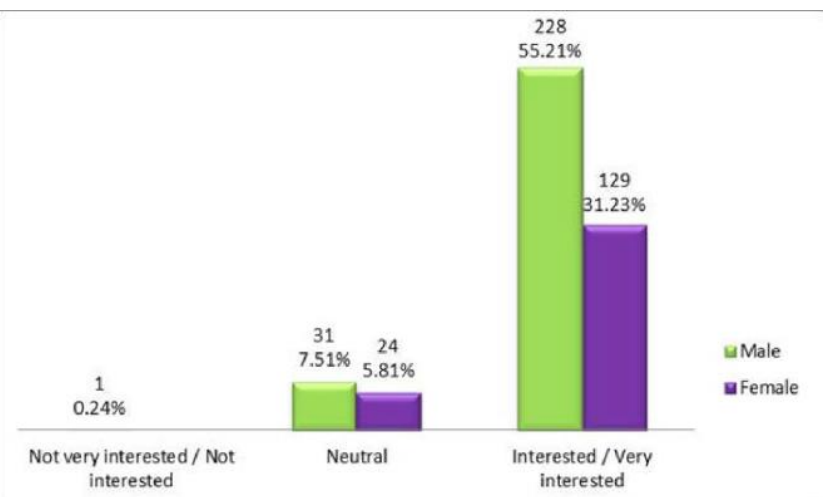

Figure 5: Interest to own a smart meter by gender

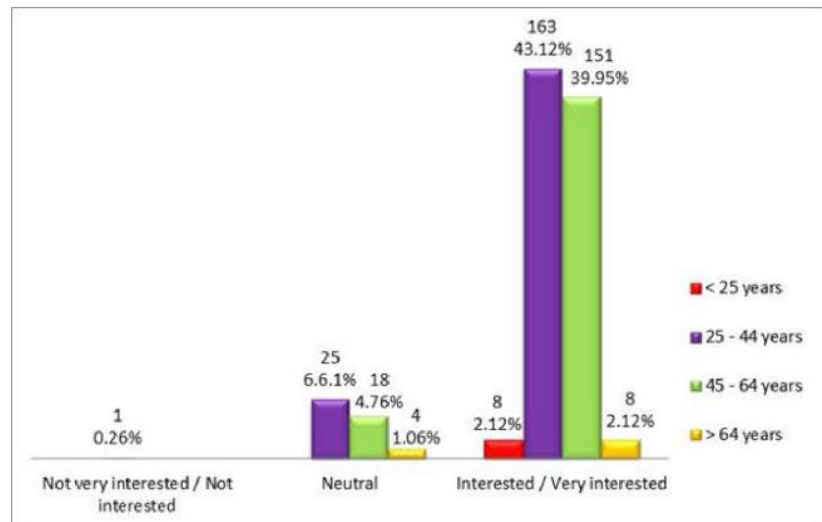

Figure 6: Interest to own a Smart Meter by age group 


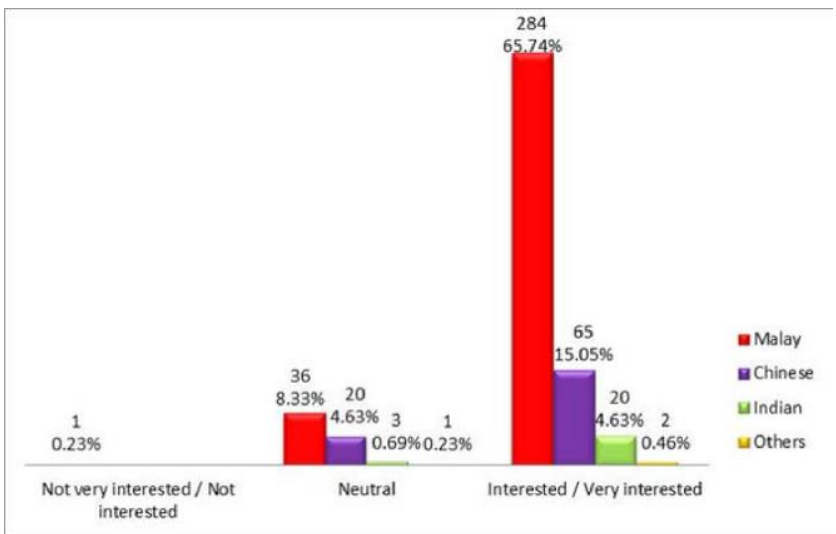

Figure 7: Interest to own a Smart Meter by educational background

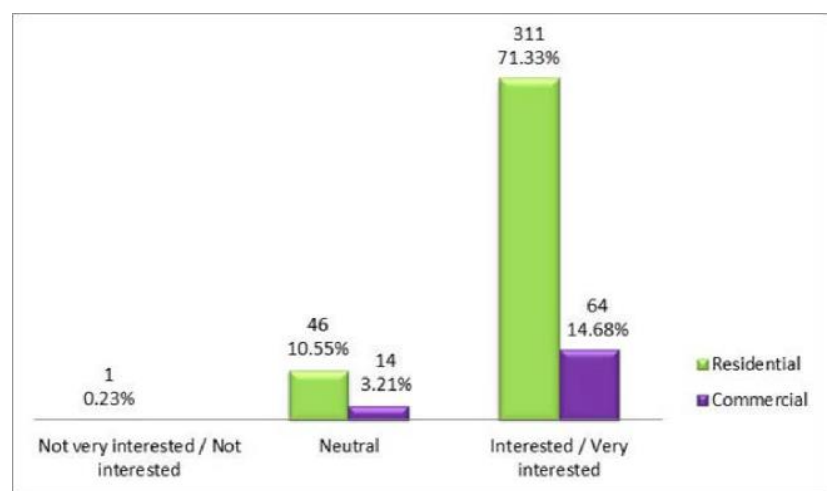

Figure 8: Interest to own a Smart Meter by monthly income

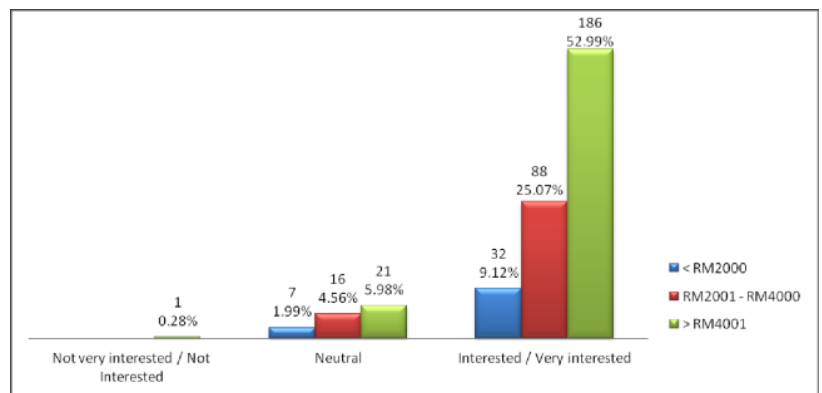

Figure 9: Interest to own a Smart Meter by type of customer

\subsection{Conclusion}

This study shows that TNB customers in Melaka, regardless of demographic profiles and background, have overall good awareness of smart living concepts which was reflected in their positive feedbacks towards the smart meter. Hence, smart meter deployment in Melaka is considered feasible. The study shows that customer trusts information originating directly from TNB instead of other information providers.

\section{Acknowledgements}

The authors gratefully acknowledge Tenaga Nasional Berhad (TNB) in providing the Research Grant (Project Number: 20141118007) and Tenaga Nasional Berhad Research Sdn. Bhd. (TNBR) in assisting us throughout this project.

\section{References}

Anonymous, 2015. Smart meters China: Beijing to hit 100\% residential coverage by year-end. State Grid Corporation of China. Retrieved from http://www.metering.com/smart-meters-china-beijing-to-hit-100-residential-coverage-by-year-end/. Dated 24 April 2015.

Depuru S.S.S.R., Wang L., Devabhaktuni V., Gudi N. ( 2011). Smart Meters for Power Grid - Challenges, issues, advantages and status, Power System Conference and Exposition (PSCE), pp 1-7, 2011. 
Hao X. , Wang Y. , Wu C., Wang A.Y. , Song L. Hu C. and Yu L. (2012). Smart Meter Deployment Optimization for Efficient Electrical Appliance State Monitoring, IEEE Third International Conference on Smart Grid Communications (SmartGridComm), pp 25-30, 2012.

U.S. DOE. "Building energy data book", 2010. Retrieved from http://buildingsdatabook.eere.energy.gov on 8 December 2014.

Vojdani, A. (2008). Smart Integration. IEEE Power \& Energy Magazine, Vol. 6, pp 71-79, Nov 2008.

Zheng J., Lin L. and David W. G. (2013). Smart Meter in Smart Grid: On Overview, IEEE Green Technologies Conference, pp 57-64, 2013. 